\title{
Iron-induced Nickel Deficiency in Pecan
}

\author{
Bruce W. Wood ${ }^{1}$ \\ U.S. Department of Agriculture, Agricultural Research Service, Southeastern \\ Fruit and Tree Nut Research Laboratory, 21 Dunbar Road, Byron, GA \\ 31008-0087
}

Additional index words. antagonism, chelates, deficiency, homeostasis, micronutrient, nutrition, piconutrient, physiology, production, symptoms, toxicity

\begin{abstract}
Economic loss resulting from nickel (Ni) deficiency can occur in horticultural and agronomic crops. This study assesses whether excessive iron (Fe) can induce $\mathrm{Ni}$ deficiency. Both chelated Fe and diethylenetriaminepentaacetic acid (DPTA; a commonly used Fe-chelant) induces $\mathrm{Ni}$ deficiency in pecan [Carya illinoinensis (Wangenh.) K. Koch]. Foliar sprays of Fe [Fe-DPTA $\left.\left(1.1995 \mathrm{~g} \cdot \mathrm{L}^{-1}\right)\right]$ during early post-budbreak shoot growth can trigger, or increase in severity, Ni deficiency symptoms in the emerging pecan canopy. Deficiency is also inducible in greenhouse-grown 'Desirable' seedlings at budbreak by Fe-DPTA application to soil and to a much lesser extent by DPTA alone. Endogenous $\mathrm{Fe}$, just after budbreak, triggers $\mathrm{Ni}$ deficiency-associated distortions in pecan seedling leaf growth and morphology when the $\mathrm{Fe}: \mathrm{Ni}$ is $\approx 150$ or greater with subsequent severity being proportional to the $\mathrm{Fe}: \mathrm{Ni}$ ratio and $\mathrm{Fe}: \mathrm{Ni} \approx 1200$ or greater triggering extreme dwarfing of canopy organs. Timely treatment of symptomatic organs with foliar-applied Ni-sulfate restores normal growth, whereas foliar treatment with salts of other transition metals (titanium, vanadium, chromium, cobalt, copper, zinc, and molybdenum) of possible metabolic significance is ineffective. Results indicate that excessive endogenous Fe, and DPTA to a lesser extent, in organs and tissues during early post-budbreak growth can trigger Ni deficiency. A similar $\mathrm{Fe}$ on $\mathrm{Ni}$ antagonism may also occur with the Ni-associated nutritional physiology of other crops; thus, excessive exposure to chelated $\mathrm{Fe}$ not only triggers $\mathrm{Ni}$ deficiency in pecan, but may also occur in other horticultural and agronomic crops.
\end{abstract}

Nickel is an often-overlooked plant (Brown et al., 1987, 1990) and animal (Welch and Graham, 2005) essential micronutrient. Although Ni deficiency in plants severe enough to trigger visual symptoms is relatively rare, compared with other essential micronutrients, both visual and non-visual deficiencies may be more common than generally supposed. This is partially because of antagonistic interactions between $\mathrm{Ni}$ and certain first-period transition metals (Wood, 2010). There is a dearth of information regarding the physiology of Ni's interaction with other essential and beneficial micronutrients; however, excessive tissue zinc $(\mathrm{Zn})$ or copper $(\mathrm{Cu})$-i.e., a high $\mathrm{Zn}: \mathrm{Ni}$ or $\mathrm{Cu}: \mathrm{Ni}$ ratio-can trigger symptoms of Ni deficiency (Wood, 2010). Because of relatively great physiochemical similarity between $\mathrm{Fe}$ and $\mathrm{Ni}$, it is likely that excessive endogenous $\mathrm{Fe}$ can disrupt Ni-dependent physiology enough to trigger economic crop loss. A natural consequence of insufficient understanding is accidental

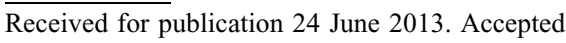
for publication 1 Aug. 2013.

I gratefully acknowledge field and laboratory assistance by James Stuckey and Kirby Moncrief. Use of trade names does not imply endorsement of the products named or criticism of similar ones not named.

${ }^{1}$ To whom reprint requests should be addressed; e-mail Bruce.Wood@ars.usda.gov.
}

induction of $\mathrm{Ni}$ deficiency in crops resulting from either excessive supplemental fertilization with certain trace metals and/or cropping on mineralized soils relatively rich in these metals.

Pecan trees growing in commercial orchards, yards, gardens, and nurseries often exhibit $\mathrm{Ni}$ deficiency during early spring when canopies are rapidly expanding. Ni deficiency often manifests itself as a potentially fatal orchard replant malady when young transplants replace missing trees in mature orchards or are planted in secondgeneration orchard sites (Wood et al., 2003a, 2003b, 2004, 2006a). Incidence and severity of deficiency vary with tree age, or size, and on the nature of the action and interaction of several biotic and abiotic soil factors (Wood et al., 2006b). Severe Ni deficiency can kill young pecan trees (Wood et al., 2004), supporting conclusions by Brown et al. (1987, 1990 ) that $\mathrm{Ni}$ is an essential nutrient element for higher plants. The fundamental cause(s) of Ni deficiency in soils containing sufficient $\mathrm{Ni}$ to meet plant needs vary but include nematode damage to feeder roots (Nyczepir et al., 2006), excessively cool and/or dry soils during early spring (Wood et al., 2006b), excessive $\mathrm{Zn}$ and/or $\mathrm{Cu}$ (Wood, 2010), and possibly excessive long-term use of glyphosate (Yamada et al., 2009).

Iron fertilizers are typically "chelates" that bind $\mathrm{Fe}^{3+}$ (ferric, or oxidized Fe). A common form is $\mathrm{Fe}$-DPTA. Iron $\left(\mathrm{Fe}^{3+}\right)$ chelates bind to the cytoplasmic plasmalemma, where, in dicots, sequestered $\mathrm{Fe}^{3+}$ is chemically reduced to $\mathrm{Fe}^{2+}$ before release from the chelant molecule and subsequent transport across the plasma membrane into the cytoplasm (Chaney et al., 1972; Romheld and Marschner, 1986). Roots can also absorb small amounts of chelants (Tiffin and Brown, 1961; Tiffin et al., 1960; Weinstein et al., 1951), which in turn can disrupt plant processes by sequestering divalent or trivalent metal ions needed for physiologically active complexes such as metalloenzymes. Pecan orchards, especially those established on relatively high $\mathrm{pH}$ soils, occasionally receive Fe-DPTA sprays for correction of $\mathrm{Fe}$ deficiency. Other field, vineyard, nursery, and hydroponic crops also receive Fe-DPTA on occasion.

Excessive orchard fertilization can trigger Ni deficiency, especially if excessively high soil/tissue $\mathrm{Zn}$ and/or $\mathrm{Cu}$ reduces the physiological availability of $\mathrm{Ni}$ within the plant (Wood, 2010; Wood et al., 2003a). Pecan foliage often exhibits visible $\mathrm{Ni}$ deficiency symptoms although the absolute foliar $\mathrm{Ni}$ concentration exceeds the apparent "lower critical" concentration (Nyczepir et al., 2006) of $\approx 0.85 \mu \mathrm{g} \cdot \mathrm{g}^{-1}$ dry weight, thus indicating that other nutrient elements can affect endogenous Ni bioavailability/use. Such micronutrient interactions are common in plants, especially in situations of extreme soil $\mathrm{pH}$ or metal composition (Kabata-Pendias, 2001). These interactions can trigger chemical stress linked to either antagonistic or synergistic effects on root uptake and/or cellular/enzymatic bioavailability/use.

There are reports of $\mathrm{Ni}$ on $\mathrm{Fe}$ antagonism in which high $\mathrm{Ni}$ reduces endogenous $\mathrm{Fe}$ concentration and/or bioavailability (Chen et al., 2009; Ghasemi et al., 2009; Hewett, 1953; Khalid and Tinsley, 1980; Koch, 1956; Kovacik et al., 2009; Misra and Dwivedi, 1977; Nicholas and Thomas, 1954; Nishida et al., 2012). However, there is little information regarding the reverse $\mathrm{Fe}$ on $\mathrm{Ni}$ antagonism, especially in woody perennials. Cataldo et al. (1978) found that $\mathrm{Fe}^{2+}$ suppresses $\mathrm{Ni}^{2+}$ absorption and translocation in soybean (Glycine max), whereas Wallace et al. (1977a) found that $\mathrm{Fe}^{3+}$ (as Fe-EDDHA) did not suppress $\mathrm{Ni}$ concentration in foliage of bush bean (Phaseolus vulgaris). Khalid and Tinsley (1980) concluded that in annual rye grass (Lolium multiflorum), it is the Ni:Fe ratio, rather than absolute concentration of either, in plant tissues and organs that is most tightly associated with reduced $\mathrm{Fe}$ bioavailability/use under high $\mathrm{Ni}$ conditions. The reverse $\mathrm{Fe}$ on $\mathrm{Ni}$ antagonism merits investigation. This study reports the effect of Fe-DPTA and DPTA on induction of $\mathrm{Ni}$ deficiency in pecan and documents a $\mathrm{Fe}$ on Ni antagonism in a long-lived woody perennial crop.

\section{Materials and Methods}

The following experiments test whether Fe-DPTA or DPTA induces or increases severity of Ni deficiency in pecan. 
Effect of foliar applied Fe on Ni deficient shoots of 'Wichita' trees: Expt. 1

A single $\approx 30$-year-old 'Wichita' tree growing in a commercial orchard near Cordele, GA, almost annually exhibits substantial Ni deficiency on certain major limbs $\approx 7 \mathrm{~d}$ after budbreak (i.e., parachute stage) with certain limbs failing to exhibit deficiency symptoms. This unique situation enabled testing of Fe's ability to influence expression of $\mathrm{Ni}$ deficiency by treating individual small $(4 \mathrm{~cm}$ or less) branches with Fe-DPTA, a common Fe-chelate (Sequestrene $330 \mathrm{Fe}$; a 10\% Fe DTPA; Novartis Crop Protection, Inc., Greensboro, NC). Treatments were: 1) nontreated $\mathrm{Ni}$-deficient control; 2) nontreated $\mathrm{Ni}$ sufficient (i.e., no visible symptoms) control; 3) Ni treatment of Ni-deficient branch; 4) Fe-DPTA treatment of Ni-deficient branch; and 5) Fe-DPTA treatment of Ni-sufficient branch. Ni was applied as Ni-sulfate (Ni at $\left.100 \mu \mathrm{g} \cdot \mathrm{L}^{-1}\right)$ and $\mathrm{Fe}$ was applied as Fe-DPTA (at $1.1995 \mathrm{~g} \cdot \mathrm{L}^{-1}$ ). Treatments were applied at the parachute stage ( $\approx 5$ to $7 \mathrm{~d}$ post-budbreak) of shoot development, immediately before onset of rapid organ growth and at a time when it became evident which branches were going to exhibit Ni deficiency sufficient to affect subsequent shoot and foliage morphology. Treatments were applied by foliar spray to runoff with treated limbs selected to avoid cross-contamination by other treatments. The experimental design consisted of five treatments replicated eight times throughout the tree's canopy $(\mathrm{n}=40)$. Statistical analysis was by analysis of variance (ANOVA) at $P \leq$ 0.05 and mean separation by Tukey's honestly significant difference (HSD) test at the same level after parameters were demonstrated to fit a normal distribution through the Shapiro-Wilk-W test for goodness of fit. Treatment effects were assessed in mid-May, $\approx 4$ weeks after application of foliar sprays. Severity of Ni deficiency was noted using a scale representing a typical progression in degree of visible Ni deficiency symptoms: $1=$ normal growth, no Ni-associated morphological distortions of shoots, compound leaves, or leaflets (i.e., normal appearance); $2=25 \%$ or less of leaflets on shoot exhibiting morphological distortions (i.e., slightly blunted leaflet apex); $3=26 \%$ to $50 \%$ of leaflets exhibiting some degree of morphological distortion; $4=$ greater than $50 \%$ of leaflets exhibiting morphological distortion; $5=\# 4$, plus leaflet cupping; $6=\# 5$, plus necrosis of leaflet tips; $7=\# 6$, plus necrosis of leaflet margins, plus crinkled and dwarfed leaflets; $8=\# 7$, plus dwarfed shoots (i.e., short internodes); $9=\# 8$, plus rosetting; and $10=\# 9$, plus shoot death (Nyczepir et al., 2006; Wood, 2010; Wood et al., 2003a, 2003b).

\section{Effect of soil-applied Fe-DPTA on Ni} deficiency in 'Desirable' trees: Expt. 2

Potted 'Desirable' trees on open-pollinated 'Elliott' rootstocks were grown in 15-L plastic pots filled with an artificial potting mix (SunGro Metro Perennial Mix; $62 \%$ to $72 \%$ composted bark, Canadian sphagnum peat, perlite, dolomite lime, and gypsum; Sun Gro, Bellevue, WA). Trees were treated at bud swell, going into their third leaf, with treatments being: 1) "control" (i.e., putative Ni-sufficient control); 2) "Fe" (3.2 g Fe-DPTA dissolved in $500 \mathrm{~mL}$ of water and applied as a soil drench); 3) "Ni" (Ni-sulfate, with $\mathrm{Ni}$ at $100 \mu \mathrm{g} \cdot \mathrm{L}^{-1}$ ) sprayed onto buds at the parachute stage of budbreak; and 4) "Fe $+\mathrm{Ni}$ " (i.e., Fe applied as a soil drench as noted previously and with $\mathrm{Ni}$ applied as a foliar spray at the parachute stage of budbreak, as described previously). The experimental design consisted of four treatments and 15 replicates per treatment with single trees serving as replicates $(n=60)$. Trees were watered as needed and received $5 \mathrm{~g}$ of urea per potted tree (i.e., urea dissolved in $500 \mathrm{~mL}$ of water and then applied to each pot at bud swell and again at budbreak). Trees were rated for severity of Ni deficiency as noted in Expt. $1 \approx 4$ weeks post-budbreak (i.e., rating the most severely affected leaflet based on the previously described rating scale). Statistical analysis was by ANOVA at $P \leq 0.05$ and mean separation by Tukey's HSD at the same level after parameters were demonstrated to exhibit fit a normal distribution through the Shapiro-Wilk-W test for goodness of fit.

\section{Effect of $\mathrm{Fe}$ : Ni ratio on expression of $\mathrm{Ni}$ deficiency: Expt. 3}

This study assessed the relationship between degree of $\mathrm{Ni}$ deficiency and tissue concentrations of $\mathrm{Ni}$ and $\mathrm{Fe}$ and the $\mathrm{Fe}: \mathrm{Ni}$ ratio of affected foliage. Open-pollinated 'Desirable' seedlings were grown in plastic pots $(15 \times 15 \times 15 \mathrm{~cm})$ containing the previously described artificial potting mix. Third-leaf seedling trees, $\approx 30$ to $40 \mathrm{~cm}$ tall, were defoliated in June to force new growth from dormant spring buds. Trees were fertilized with $1 \mathrm{~g}$ urea per pot at the time of defoliation and another gram at budbreak. Urea was applied in $100 \mathrm{~mL}$ deionized water flooded onto the surface of each pot. To achieve a gradient in Ni deficiency symptoms, the study consisted of seedlings fertilized with Fe-DTPA at different amounts per pot with there being 10 trees per rate. FeDPTA treatments were $0 \mathrm{X}, 1 \mathrm{X}, 2 \mathrm{X}, 4 \mathrm{X}, 8 \mathrm{X}$, $16 \mathrm{X}, 32 \mathrm{X}, 64 \mathrm{X}$, and $128 \mathrm{X}$; with $\mathrm{X}=\mathrm{Fe}-$ DPTA at $0.40 \mathrm{~g} /$ pot. The study used 90 seedlings. Fe-DPTA was applied once, at defoliation, by flooding the pot with the Fechelate dissolved in $300 \mathrm{~mL}$ of deionized water. Subsequent watering was such that there was no mass flow of water through the pot's soil to avoid leaching of Fe. Buds broke at several nodes $\approx 10$ to $14 \mathrm{~d}$ after defoliation. Seedlings were rated for severity of $\mathrm{Ni}$ deficiency $\approx 2$ weeks after budbreak and leaflet lamina tissue (excluding the midrib) of the new canopy sampled for micronutrients. At the same time, all foliage and shoot tissue was sampled from the largest shoot mass of the three to four nodes that broke bud. These were subsequently measured for fresh weight, dry weight, and nutrient element concentration. Nutrients analyzed were first period transition elements [i.e., titanium (Ti), valadium
(V), chromium ( $\mathrm{Cr}$ ), manganese $(\mathrm{Mn}), \mathrm{Fe}$, cobalt $(\mathrm{Co}), \mathrm{Ni}$, copper $(\mathrm{Cu}), \mathrm{Zn}$, plus molybdenum (Mo)]. Foliage collection used zirconium oxide ceramic scissors to avoid metal contamination of samples. Nickel deficiency of seedlings was verified by restoration of normal growth in the youngest emerging shoots after treating a subpopulation of symptomatic seedlings with analyticalgrade Ni-sulfate (i.e., $\mathrm{Ni}$ at $\approx 100 \mu \mathrm{g} \cdot \mathrm{mL}^{-1}$ ) sprayed on the leaf lamina $\approx 7 \mathrm{~d}$ post-budbreak.

Sample processing. Leaflet samples were air-dried to a constant weight at room temperature, diced using zirconium oxide ceramic scissors with small pieces thoroughly mixed in an acid-rinsed plastic container, and then 100 to $500 \mathrm{mg}$ of bulked tissue placed in nylon tubes for processing. Sample digestion used $10 \mathrm{~mL}$ of $70 \%$ ultra-low trace elementgrade nitric acid (Sigma-Aldrich, Atlanta, GA) in a MarsXpress carousel placed within a Mars-5 (CEM Corporation, Matthews, NC) microwave digester. Cooled samples were filtered and brought to $20 \mathrm{~mL}$ (by weight; using $2 \%$ nitric acid) in $50-\mathrm{mL}$ polypropylene centrifuge tubes and $0.5 \mathrm{~mL}$ ( or $0.100 \mathrm{~mL}$, for certain elements) added to a $15-\mathrm{mL}$ plastic tube and brought up to $14.5 \mathrm{~mL}$ using a $2 \%$ nitric acid solution in preparation for metal analysis.

Inductively coupled plasma mass spectrophotometry analysis. The concentration of $\mathrm{Ti}, \mathrm{V}, \mathrm{Cr}, \mathrm{Mn}, \mathrm{Co}, \mathrm{Cu}, \mathrm{Zn}, \mathrm{Mo}, \mathrm{Fe}$, and $\mathrm{Ni}$ in leaf tissue samples was determined using an inductively coupled plasma mass spectrophotometer; PerkinElmer SCIEX ELAN-9000; Concord, Ontario, CA). Quantitative analysis was facilitated by a similar mass internal standard $\left({ }^{72} \mathrm{Ge}\right)$ and external standards using multielement standard solutions (PerkinElmer Multielement Calibration Standard Sets) diluted to cover three to four orders of magnitude. Each sample was analyzed in triplicate.

Statistical analysis. Differential application of Fe produced a population of seedlings exhibiting $\mathrm{Ni}$ deficiency symptoms covering most of the entire rating range reflecting symptom severity. Measured parameters were therefore analyzed by curvilinear regression for the seedling population.

\section{Efficacy of transition metals for correcting $\mathrm{Fe}$ induced $\mathrm{Ni}$ deficiency symptoms: Expt. 4}

Because of an association between concentrations of certain other transition metals and severity of Fe-induced Ni deficiencylike symptoms, these other transition metals were also tested for their ability to correct $\mathrm{Ni}$ deficiency. These were: $\mathrm{Ti}\left(\mathrm{TiH}_{2}\right), \mathrm{V}\left(\mathrm{VCl}_{2}\right)$, $\mathrm{Cr}\left[\mathrm{Cr}_{2}\left(\mathrm{SO}_{4}\right)_{3} \cdot \mathrm{xH}_{2} \mathrm{O}\right] ; \mathrm{Mn}\left(\mathrm{MnCl}_{2} \cdot 4 \mathrm{H}_{2} \mathrm{O}\right)$; $\mathrm{Fe}\left(\mathrm{FeSO}_{4} \cdot 7 \mathrm{H}_{2} \mathrm{O}\right) ; \mathrm{Co}\left(\mathrm{CoSO}_{4} \cdot 7 \mathrm{H}_{2} \mathrm{O}\right) ; \mathrm{Ni}$ $\left(\mathrm{NiSO}_{4} \cdot 7 \mathrm{H}_{2} \mathrm{O}\right) ; \mathrm{Cu}\left(\mathrm{CuSO}_{4} \cdot 7 \mathrm{H}_{2} \mathrm{O}\right) ; \mathrm{Zn}$ $\left(\mathrm{ZnSO}_{4} \cdot 7 \mathrm{H}_{2} \mathrm{O}\right)$; and $\mathrm{Mo}\left(\mathrm{H}_{2} \mathrm{MoO}_{4}\right)$. All were applied as a foliar spray $\approx 7 \mathrm{~d}$ post-budbreak with metal concentration at $25 \mu \mathrm{g} \cdot \mathrm{L}^{-1}$ for each transition metal. The study consisted of Fe-induced Ni deficiency in 'Desirable' seedling trees as described in the previous experiment (Expt. 3). The experiment design 
consisted of two treatments for each transition metal being tested-i.e., emerging shoots of symptomatic seedling were divided into either "symptomatic nontreated control" or "symptomatic + transition metal" treatments and treated accordingly with the relevant transition metal solution. Seedling shoot treatments were subsequently rated as described previously for severity of morphologically based Ni-like deficiency symptoms exhibited $\approx 10 \mathrm{~d}$ posttreatment. The study used 14 replications for each transition metal tested. The study was analyzed by ANOVA to determine treatment effects.

\section{Influence of DPTA and FeDPTA on Ni deficiency symptoms: Expt. 5}

Chelating agents are potentially absorbed by roots and then xylem transported to the canopy where they can traverse the cellular plasma membranes and sequester metals within the cellular cytoplasm of developing canopy tissues. Two experiments were conducted to assess the possibility that the DPTA chelant might be the causal factor for triggering $\mathrm{Ni}$ deficiency rather than Fe. Both used 2-year-old open-pollinated seedling 'Desirable' trees grown in a potting mix as described in Expt. 2.

In Study 1, seedlings were defoliated, fertilized with urea, and then treated through a soil drench with 1) deionized water control; 2) DPTA (at 500 mmoles/pot); 3) Fe-DPTA (at 500 mmoles/pot); 4) control plus Ni; 5) DPTA plus Ni; or 6) FeDPTA plus Ni. Nickel was applied as a foliar spray of Ni-sulfate (Ni-sulfate, with $\mathrm{Ni}$ at $2 \mathrm{~mm}$ ) $\approx 7 \mathrm{~d}$ postbudbreak, whereas the DPTA and FeDPTA treatments were by soil application. Seedlings were rated for Ni deficiency symptoms as described previously.

In Study 2, seedlings were defoliated, fertilized with urea, and then treated by a foliar spray $\approx 6 \mathrm{~d}$ post-budbreak with 1 ) deionized water control; 2) DPTA (at $3 \mathrm{~mm}$ ) or 3) Fe-DPTA (at $3 \mathrm{~mm}$ ); 4) control plus Ni; 5) DPTA plus Ni; or 6) FeDPTA plus Ni. Nickel was applied as a foliar spray of Ni-sulfate (Ni-sulfate, with $\mathrm{Ni}$ at $2 \mathrm{~mm}$ ) $\approx 7 \mathrm{~d}$ postbudbreak and again $\approx 10 \mathrm{~d}$ post-budbreak. The seedlings were foliarly sprayed in a manner that ensured no DPTA and Fe-DPTA was deposited onto the potting soil mix in which trees were growing, thus ensuring that DPTA or Fe-DPTA had effects on expanding foliage from canopy absorption rather than from root absorption. Seedlings were rated for Ni deficiency symptoms as described previously, $\approx 4$ weeks after treatment.

The experimental design consisted of six treatments replicated eight times $(\mathrm{n}=48)$. Statistical analysis was by ANOVA at $P \leq$ 0.05 and mean separation by Tukey's HSD test at the same level after parameters were demonstrated to fit a normal distribution through the Shapiro-Wilk-W test for goodness of fit.

\section{Results}

These experiments indicated that either soil- or foliar-applied Fe, when sequestered by DPTA, is capable of inducing $\mathrm{Ni}$ deficiency. Observed changes in pecan leaf and shoot morphology were fully consistent with previously demonstrated symptoms caused by Ni deficiency (Nyczepir et al., 2006; Wood et al., 2003a, 2004). Because Fe-induced symptoms were fully reversible by timely Ni treatment, the following discussion of results is couched within the context of $\mathrm{Fe}$ induced Ni deficiency instead of Fe toxicity.

Effect of foliar-applied $\mathrm{Fe}$ on Ni deficient shoots of 'Wichita' trees: Expt. 1. Timely Fe treatment of emerging 'Wichita' shoots and foliage increased severity of Ni deficiency symptoms after spring budbreak (Table 1). Non-treated Ni-deficient shoots exhibited relatively severe $\mathrm{Ni}$ deficiency with a mean rating of 6.4 on a Ni deficiency severity scale (i.e., ranging from 1 to 10). Treatment of Nideficient shoots with Ni-sulfate at the parachute stage of shoot development typically corrected $\mathrm{Ni}$ deficiency (i.e., 1.1 rating). By comparison, shoots asymptomatic of $\mathrm{Ni}$ deficiency soon after budbreak also exhibited little or no deficiency later in the spring (i.e., 1.3 rating); hence, it was clear that shoots exhibiting deficiency symptoms were indeed Ni-deficient. Application of $\mathrm{Fe}$ to Nideficient shoots substantially increased severity of $\mathrm{Ni}$ deficiency in symptomatic (i.e., 7.5 rating) shoots. Similarly, Fe treatment of asymptomatic Ni-deficient shoots triggered $\mathrm{Ni}$ deficiency (i.e., 4.5 rating); thus, increasing tissue $\mathrm{Fe}$ concentration of either $\mathrm{Ni}$ deficient, or near deficient, tissue can either increase the severity of $\mathrm{Ni}$ deficiency or trigger visual deficiency symptoms.

Effect of soil-applied Fe on Ni deficiency in 'Desirable' seedling: Expt. 2. Exposure of 'Desirable' seedling trees to high amounts of $\mathrm{Fe}$ fertilizer (Fe-DPTA) triggered Ni deficiency symptoms in leaflets of new compound leaves (Table 2). The other treatments, the "Ni sufficient control," "Ni applied to foliage" (i.e., Ni sulfate applied to foliage of Ni-sufficient trees), and "Fe applied to soil plus $\mathrm{Ni}$ applied to foliage" (i.e., of Nisufficient trees), did not exhibit morphological symptoms of Ni deficiency. However, the "Fe applied to soil" treatment triggered relatively severe Ni deficiency (i.e., 6.1 severity rating). This greenhouse experiment confirms the previous field experiment that excessive $\mathrm{Fe}$ at the time of budbreak can trigger $\mathrm{Ni}$ deficiency in rapidly expanding foliage.

Effect of $\mathrm{Fe}: \mathrm{Ni}$ ratio on expression of $\mathrm{Ni}$ deficiency: Expt. 3. The shoot dry weight of Fe-treated seedlings increased as foliar $\mathrm{Ni}$ concentration increased (Fig. 1A) with dry weight peaking at $\mathrm{Ni}$ concentration of $\approx 5$ $\mu \mathrm{g} \cdot \mathrm{g}^{-1}$ dry weight. $\mathrm{Fe}$, as Fe-DPTA, applied to potted soil was rapidly absorbed by seedlings to increase the concentration of $\mathrm{Fe}$ in foliage of new shoots (Fig. 1B) with there being a curvilinear decline in shoot dry weight as leaflet $\mathrm{Fe}$ concentration increases $\approx 300 \mu \mathrm{g} \cdot \mathrm{g}^{-1}$ dry weight or greater. This relatively high leaflet $\mathrm{Fe}$ concentration led to substantial reductions in seedling apical shoot dry weight.
Table 1. Influence of post-budbreak (i.e. parachute stage) application of irondiethylenetriaminepentaacetic acid (Fe-DTPA) to 'Wichita' pecan branches (i.e., shoots and foliage) on subsequent expression of nickel (Ni) deficiency symptoms of early spring growth.

\begin{tabular}{lc}
\hline & $\begin{array}{c}\text { Severity of } \\
\text { Ni deficiency } \\
\text { Shoot treatment }\end{array}$ \\
\hline $\begin{array}{c}\text { Nontreated Ni-deficient } \\
\text { control }\end{array}$ & $6.4 \mathrm{~b}^{\mathrm{x}}$.) \\
$\begin{array}{l}\text { Nontreated Ni-sufficient } \\
\text { control }\end{array}$ & $1.3 \mathrm{~d}$ \\
$\begin{array}{l}\text { Ni-treated Ni-deficient } \\
\text { branch }\end{array}$ & $1.1 \mathrm{~d}$ \\
$\begin{array}{l}\text { Fe-DPTA-treated Ni-deficient } \\
\text { branch }\end{array}$ & $7.5 \mathrm{a}$ \\
$\begin{array}{c}\text { Fe-DPTA treatment of } \\
\text { Ni-sufficient branch }\end{array}$ & $4.5 \mathrm{c}$ \\
\hline
\end{tabular}

${ }^{\mathrm{z}}$ Shoots were treated $\approx 7$ to $10 \mathrm{~d}$ after inner budscale budbreak, which corresponds to the parachute stage of budbreak.

${ }^{\mathrm{y}} \mathrm{Severity}$ of $\mathrm{Ni}$ deficiency was assessed in midMay, A 4 weeks after treatment, according to the following rating scale identifying a progression in degree of visible Ni deficiency symptoms: $1=$ no Ni-associated morphological distortions of shoots, compound leaves, or leaflets (i.e., normal appearance); $2=25 \%$ or less of leaflets on shoot exhibiting morphological distortions (i.e., slightly blunted leaflet apex); $3=26 \%$ to $50 \%$ of leaflets exhibiting some degree of morphological distortion; 4 = greater than $50 \%$ of leaflets exhibiting morphological distortion; $5=\# 4$, plus leaflet cupping; $6=\# 5$, plus necrosis of leaflet tips; $7=\# 6$, plus necrosis of leaflet margins, plus crinkled and dwarfed leaflets; $8=\# 7$, plus dwarfed shoots (i.e., short internodes); $9=\# 8$, plus rosetting; and $10=$ \#9, plus shoot death (Nyczepir et al., 2006; Wood, 2010; Wood et al., 2003a, 2003b).

xTreatment means followed by different letters (i.e., a non-common letter) are significantly different by Tukey's honestly significant difference at $P \leq 0.05$ level.

When viewed within the context of morphologically based visual Ni deficiency symptoms, there was a substantial increase in severity of Ni deficiency as foliar Ni concentration decreased (Fig. 2A) with concentration $\approx 1.5 \mu \mathrm{g} \cdot \mathrm{g}^{-1}$ or less being associated with some degree of visual $\mathrm{Ni}$ deficiency and greater than $\approx 5 \mu \mathrm{g} \cdot \mathrm{g}^{-1}$ being symptom-free. Conversely, severity of $\mathrm{Ni}$ deficiency increased curvilinearly as foliar Fe concentration increased (Fig. 2B) with deficiency being especially severe at $\mathrm{Fe}$ concentrations of $\approx 600$ to $700 \mu \mathrm{g} \cdot \mathrm{g}^{-1}$ or greater; thus, excessive $\mathrm{Fe}$ can cause Ni deficiency. Although there is evidence that elevating $\mathrm{Fe}$ can slightly reduce leaflet $\mathrm{Ni}$ (Fig. 3; perhaps attributable either to slightly reduced Ni uptake by roots or reduced mobilization to foliage), there is little evidence of $\mathrm{Fe}$-associated suppression through mechanisms regulating the absolute concentration of $\mathrm{Ni}$ within new expanding foliage. Thus, foliar Fe concentration appears to be influencing foliar bioavailability/use of $\mathrm{Ni}$ for growth processes.

On examination of the effect of different $\mathrm{Fe}: \mathrm{Ni}$ ratios on shoot dry weight, it is apparent that shoot dry weight is sensitive to the endogenous Fe:Ni ratio (Fig. 4A). A Fe:Ni ratio of $\approx 150$ or greater appears to lead to 
Table 2. Influence of soil application of irondiethylenetriaminepentaacetic acid (Fe-DPTA) on nickel $(\mathrm{Ni})$ deficiency exhibited by early spring growth of 'Desirable' pecan seedlings grow in pots.

\begin{tabular}{lc}
\hline Pot/seedling treatment & $\begin{array}{c}\text { Severity of } \\
\text { Ni deficiency } \\
\text { (scale no.) }^{\mathrm{y}}\end{array}$ \\
\hline Ni-sufficient control & $1.0 \mathrm{~b}^{\mathrm{x}}$ \\
Fe applied to soil & $6.1 \mathrm{a}$ \\
Ni applied to foliage & $1.0 \mathrm{~b}$ \\
Fe applied to soil plus & $1.0 \mathrm{~b}$ \\
$\quad$ Ni applied to foliage & \\
\hline
\end{tabular}

${ }^{2}$ Shoots were treated $\approx 7$ to $10 \mathrm{~d}$ after inner budscale budbreak, which corresponds with the parachute stage of budbreak. All seedlings trees of all treatments were Ni-sufficient at the time of treatment with no expression of visible symptoms of Ni deficiency.

${ }^{y}$ Severity of Ni deficiency was assessed in midMay, $\approx 4$ weeks after treatment, according to the following rating scale identifying a progression in degree of visible Ni deficiency symptoms: $1=$ no Ni-associated morphological distortions of any compound leaves or leaflets on shoots (i.e., normal appearance); $2=25 \%$ or less of leaflets on most severely distorted compound leaf exhibiting morphological distortions (i.e., slightly blunted leaflet apex); $3=26 \%$ to $50 \%$ of leaflets on this compound leaf exhibiting some degree of morphological distortion; $4=$ greater than $50 \%$ of leaflets on this compound leaf exhibiting morphological distortion; $5=\# 4$, plus leaflet cupping; $6=\# 5$, plus necrosis of leaflet tips; $7=\# 6$, plus necrosis of leaflet margins, plus crinkled and dwarfed leaflets; $8=\# 7$, plus dwarfed shoots (i.e., short internodes); $9=\# 8$, plus rosetting; and $10=\# 9$, plus shoot death (Nyczepir et al., 2006; Wood, 2010; Wood et al., 2003a; 2003b).

${ }^{x}$ Treatment means followed by different letters (i.e., a non-common letter) are significantly different by Tukey's honestly significant difference at $P \leq 0.05$ level.

major suppression of shoot growth with a ratio 1200 or greater resulting in especially dwarfed growth. Similarly, the severity of morphologically based Ni deficiency symptoms increases curvilinearly as the $\mathrm{Fe}: \mathrm{Ni}$ ratio increases (Fig. 4B) with severity of symptoms being substantial at a ratio of $\approx 150$ or greater and exceedingly severe at a ratio of $\approx 600$ or greater.

Efficacy of transition metals for correcting Fe induced Ni deficiency symptoms: Expt. 4. It is noteworthy that severity of Fe-DPTAinduced Ni deficiency was weakly associated with increases in foliar concentration of certain other transition metals $[\mathrm{Ti}, \mathrm{V}, \mathrm{Cr}$, $\mathrm{Co}, \mathrm{Cu}, \mathrm{Zn}$, and Mo (Fig. 5)]; however, there was no additional accumulation of $\mathrm{Ti}$ and $\mathrm{Mn}$. These weak relationships are potentially attributable to several factors such as 1) transition metal contamination of the commercial-grade Fe-DPTA; 2) Fe-triggered enhancement of transition metal uptake by roots; 3) $\mathrm{Fe}$-triggered remobilization of transition metals already in the seedlings to developing foliage; or 4) elevation of tissue concentration in proportion to $\mathrm{Ni}$-associated reductions in dry weight of expanding organs. The elevation of metal concentration in Ni-deficient foliage is evidence that the change in transition metal concentration was

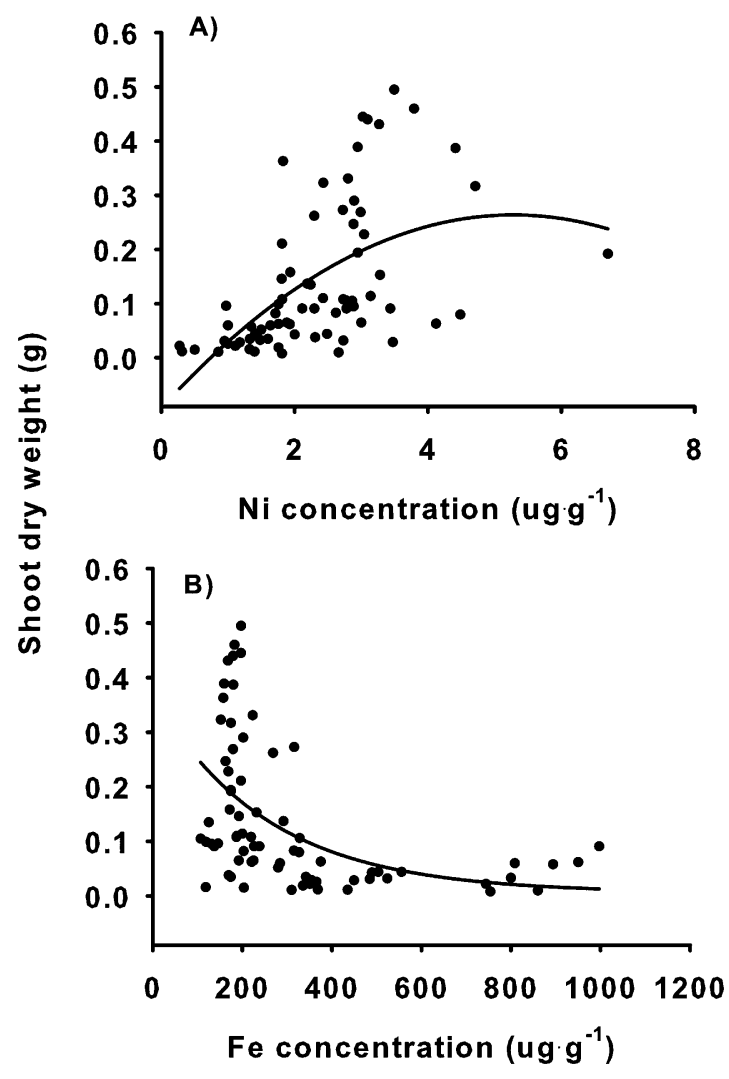

Fig. 1. Relationship between the dry weight $(y)$ of the apical-most shoot of pecan seedlings, $\approx 14 \mathrm{~d}$ after budbreak, and foliar concentration of either nickel $(\mathrm{Ni})(x ; \mathbf{A})$ or iron $(\mathrm{Fe})(x ; \mathbf{B})$. The relationship is described by a polynomial (quadratic) function for $\mathbf{A}$ where $y=-9.281^{\mathrm{e}-2}+1.351^{\mathrm{e}-1} x-1.280^{\mathrm{e}-2} x^{2} ; R^{2}=$ $0.31, P=0.05$. The relationship is described by an exponential decay function for $\mathbf{B}$ where $y=5.743^{\mathrm{e}-3}+$ $3.644 \mathrm{e}-1^{-3.944 \mathrm{e}-3 x} ; R^{2}=0.24, P=0.05$.

related to a substantial reduction in tissue dry weight of Ni-deficient organs. The concentration of $\mathrm{Ti}, \mathrm{V}, \mathrm{Cr}, \mathrm{Mn}, \mathrm{Ni}, \mathrm{Co}, \mathrm{Cu}, \mathrm{Zn}$, and Mo in the commercial Fe-DPTA product was very low [i.e., less than $0.5 \%$ by weight (data not shown)] but still high enough to account for elevated trace metal concentrations in leaf tissue. This was especially likely if some of these trace metals were eventually chelated with DPTA freed up after detaching from $\mathrm{Fe}$ ions and then became easier for roots to absorb. Foliar treatment of symptomatic seedlings with the various non-Ni transition metals within $\approx 7$ to $10 \mathrm{~d}$ after budbreak failed to improve or restore normal shoot/ foliar growth (Table 3) or to worsen growth; however, Ni-sulfate restored normal shoot growth. This verifies that observed Fe-DPTAassociated symptoms are indeed the result of Ni deficiency (Fig. 6). This links the observed Ni deficiency to Fe rather than that of other transition element metals ( Ti, V, Co, Mn, Co, $\mathrm{Cu}, \mathrm{Zn}$, or $\mathrm{Mo}$ ).

Influence of DPTA and FeDPTA on Ni deficiency symptoms: Expt. 5. It was apparent that both DPTA and Fe-DPTA can trigger $\mathrm{Ni}$ deficiency in pecan seedlings, regardless of whether they are soil- or foliar-applied, if applied just after budbreak (Table 4). The prevention of Ni deficiency in either DPTAor Fe-DPTA-treated plants by foliar Ni sprays $1 \mathrm{~d}$ and $4 \mathrm{~d}$ posttreatment indicates that the $\mathrm{Ni}$ associated distortion in foliar morphology was indeed the result of the effects of both DPTA and $\mathrm{Fe}$ on the endogenous physiological bioavailability of $\mathrm{Ni}$ within treated foliage. The severity of Ni deficiency was substantially greatest in seedlings treated with Fe-DPTA than with an equal molar amount of DPTA. These findings are suggestive that $\mathrm{Ni}$ deficiency was not only triggered by Fe-DPTA, but to a lesser degree by the DPTA chelating agent; however, it was the Fe component of the chelate that is most active in triggering $\mathrm{Ni}$ deficiency symptoms.

\section{Discussion}

These experiments indicate that excessive Fe disrupts certain aspects of micronutrient homeostasis (i.e., processes ensuring that the various endogenous environments of cells is such that these metals are maintained within a non-toxic physiological range) during the post-budbreak canopy expansion growth phase of pecan. Either excessive Fe appears to trigger an imbalance in the endogenous concentration of physiologically available $\mathrm{Ni}$ or $\mathrm{Fe}$ is competing with $\mathrm{Ni}$ at metabolically/ physiologically relevant sites. For example, $\mathrm{Fe}$ can substitute for $\mathrm{Ni}$ in urease of the gastric pathogen, Heliocobacter mustelae, but diminishes urease activity (Carter et al., 2011). An Fe-induced Ni deficiency potentially affects a host of Ni-associated endogenous processes such as Ni-associated 


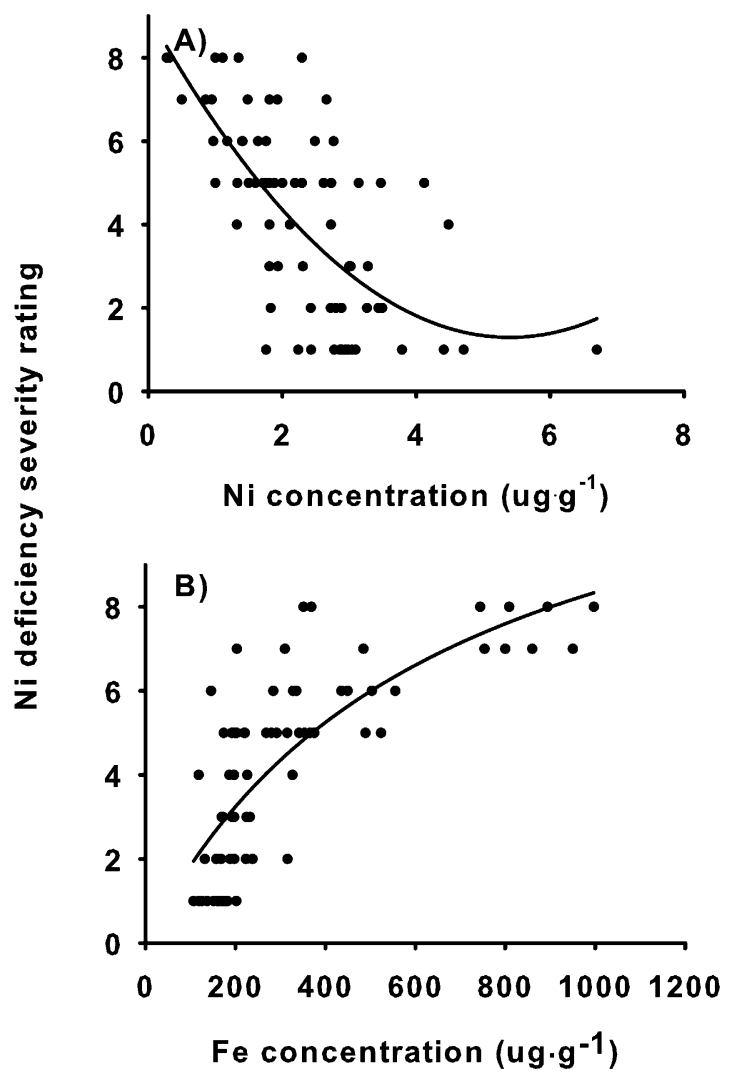

Fig. 2. Relationship between degree of nickel $(\mathrm{Ni})$ deficiency $(y)$ of the apical-most shoot of pecan seedlings, $\approx 14 \mathrm{~d}$ after budbreak, and foliar concentration of either $\mathrm{Ni}(x ; \mathbf{A})$ or iron $(\mathrm{Fe})(x ; \mathbf{B})$. The relationship is described by a polynomial (quadratic) function for $\mathbf{A}, y=9.036^{\mathrm{e}+0}-2.867^{\mathrm{e}} x+2.655^{\mathrm{e}-1} x$; $R^{2}=0.47, P=0.05$. The relationship is described by a hyperbolic function for $\mathbf{B}, y=\left(1.375^{\mathrm{e}+1} x\right)$ $\left(6.483^{\mathrm{e}+2}+x\right) ; R^{2}=0.59, P=0.05$.

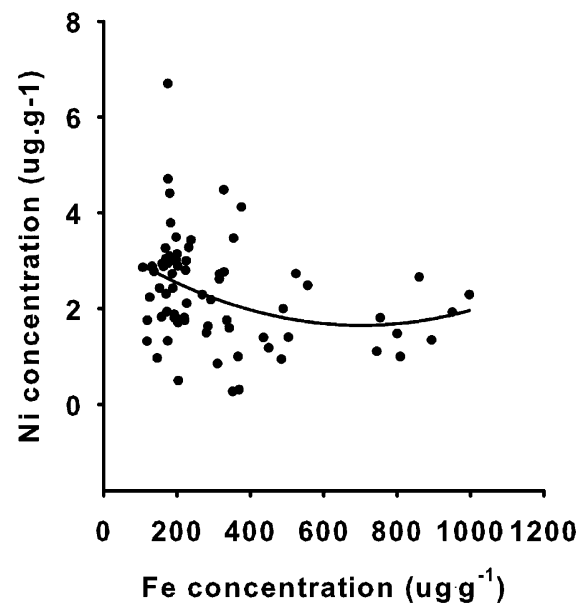

Fig. 3. Relationship between nickel (Ni) $(y)$ and iron $(\mathrm{Fe})(x)$ concentration within foliage from the apical-most shoot of pecan seedlings $\approx 14$ $\mathrm{d}$ after budbreak. The relationship is described by a polynomial (quadratic) function where $y=$ $3.382^{\mathrm{e}+0}-4.924^{\mathrm{e}-1} x+3.506^{\mathrm{e}-6} x^{2} ; R^{2}=0.11, P=$ 0.05 .

metalloprotein assembly pathways during preliminary assembly when relatively great polypeptide/protein flexibility reduces the selectivity of metal-binding sites (Merchant, 2010). It is therefore reasonable to postulate that the harmful Fe-Ni antagonism exhibited slight Fe-induced reduction in leaf $\mathrm{Ni}$ concentration in the present study, it was small at best and does not provide strong evidence for an $\mathrm{Fe}$-induced inhibition of $\mathrm{Ni}$ uptake by roots or transport to expanding shoots. Thus, evidence implicates an Fe-induced disruption of cellular homeostasis, most likely because of sudden high availability of $\mathrm{Fe}$ at a time of relatively great organ demand for $\mathrm{Fe}$ and a subsequent loading of free $\mathrm{Fe}$ within cells. Transition metals require exquisite handling within cells to ensure that free metal species do not harm cellular machinery (Sekhon, 2010). In the case of rapidly growing pecan organs, excessive free Fe disrupts Ni-associated plant nutrition. Perhaps this is the result of disruption in equilibrium or efficacy of metal transporters and/or metallochaperones.

The antagonistic effect of $\mathrm{Fe}$ on $\mathrm{Ni}$ is partially the result of similarity in the ionic radii $\left(r_{\mathrm{rad}}\right)$ of $\mathrm{Fe}^{2+}\left(r_{\mathrm{rad}}=61 \mathrm{PM}\right.$ and $78 \mathrm{PM}$, depending on spin-state and coordination number) and $\mathrm{Ni}^{2+}\left(r_{\text {rad }}=70 \mathrm{PM}\right)$ (McGlashan, 2010 ); thus, this $r_{\text {rad }}$ similarity indicates that it is likely that $\mathrm{Fe}^{2+}$ ions compete with $\mathrm{Ni}^{2+}$ ions in certain metabolic/physiological processes. Because of the Ni-Fe antagonism observed here, it appears likely that in cases where Ni toxicity is a problem with crops, appropriate elevation of crop $\mathrm{Fe}^{2+}$ concentration affords a means of correcting the problem. In that situation, $\mathrm{Ni}$ might have the greatest effect on $\mathrm{Fe}$-dependent oxidoreductases (EC1), because they comprise by far the greatest proportion of $\mathrm{Fe}$-containing proteins (i.e., oxidoreductases vs. transferases, hydrolases, lyases, isomerases, and ligases) (Waldon et al., 2009). Conversely, when crops are either deficient or marginally sufficient, in biologically available $\mathrm{Ni}$, then soil or crop management conditions that substantially elevate endogenous bioavailable $\mathrm{Fe}^{2+}$ might disrupt $\mathrm{Ni}$-associated metabolism and trigger either invisible hidden hunger or visible forms of $\mathrm{Ni}$ deficiency. For example, the author has observed Fe-chelate-induced $\mathrm{Ni}$ deficiency in a commercial European plum (Prunus domestica) orchard on an alkaline limestone soil with trees receiving supplemental chelated $\mathrm{Fe}$, by drip irrigation, in an attempt to correct/prevent Fe deficiency. Because $\mathrm{Ni}$ is key to certain aspects of nitrogen (N) metabolism, especially in crop species where $\mathrm{N}$ is transported as ureides, crop $\mathrm{N}$ use efficiency for physiological processes might substantially suffer if the $\mathrm{Fe}: \mathrm{Ni}$ ratio is excessively high. Apparent differences in Ni sufficiency concentration thresholds among plant species (e.g., ureide vs. non-ureide transporters) indicate that the optimum Fe:Ni ratio, or ratio for triggering $\mathrm{Ni}$ antagonisms, likely varies among crop species.

The ability of $\mathrm{Fe}$ to disrupt Ni-associated physiology raises the possibility of disrupting metabolic processes dependent on certain other metals. According to the thermodynamic preferences described by the IrvingWilliams series $\left(\mathrm{Zn}^{2+}<\mathrm{Cu}^{+1}>\mathrm{Cu}^{2+}>\mathrm{Ni}^{2+}>\right.$ $\left.\mathrm{Co}^{2+}>\mathrm{Fe}^{2+}>\mathrm{Mn}^{2+}>\mathrm{Mg}^{2+}>\mathrm{Ca}^{2+}\right)$, the series' cations bind to organic ligands such as the 

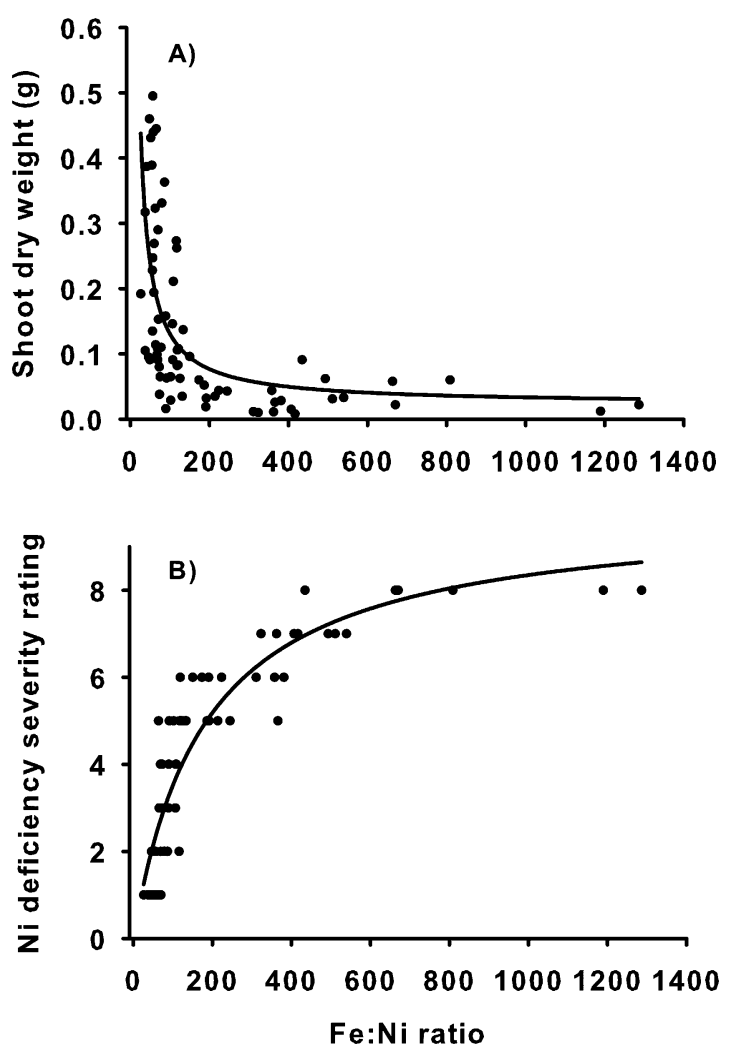

Fig. 4. Relationship between shoot dry weight (y) or degree of nickel (Ni) deficiency (y) and foliar iron $(\mathrm{Fe})$ :Ni ratio $(x)$. The relationship is described by an inverse first-order polynomial function for shoot dry weight (A), where $y=6.979^{\mathrm{e}+0}+\left(-2.699^{\mathrm{e}+2} / x\right) ; R^{2}=0.75, P=0.05$. The relationship is described by a hyperbolic function for degree of Ni deficiency $(\mathbf{B})$ where $y=\left(9.854^{\mathrm{e}+0} x\right) /\left(1.802^{\mathrm{e}+2}+x\right) ; R^{2}=0.81$, $P=0.05$.

many hundreds of apometalloprotein species found in crops with different affinities (Kramer and Clemens, 2006; Nieboer and Richardson, 1980). Although this series indicates that $\mathrm{Fe}^{2+}$ binding should be weaker than that of $\mathrm{Ni}^{2+}$ for $\mathrm{Ni}$-associated apometalloproteins, these experiments imply that mitigating factors (e.g., spatial constraints associated with the binding site, electron charge density, ionic radii, and reduced selectivity of metal-bind sites on polypeptides before final protein spatial state) are driving the Fe-on-Ni interaction. Because histidine is likely a primary Ni carrier, through histidine side chains of peptides and proteins, in $\mathrm{Ni}$ uptake and xylem transport, it is possible that $\mathrm{Fe}$ interferes with one or both of these processes. Although the Irving-Williams series indicates that $\mathrm{Fe}^{2+}$ could also be interfering with $\mathrm{Mn}^{2+}, \mathrm{Mg}^{2+}$, and $\mathrm{Ca}^{2+}$-associated sites, the degree of disruption is obviously minor compared with that of $\mathrm{Ni}^{2+}$ sites in that timely foliar sprays with Ni rapidly correct visible deficiency symptoms and restore normal growth of growing organs. The ability of excessive $\mathrm{Fe}$ to disrupt Ni-associated nutritional physiology of pecan, and ability of foliar Ni application to easily overcome this antagonism, indicates that one or more key Ni-dependent metabolic processes are highly $\mathrm{Ni}$-specific and are not accommodated by the other elements of the $\mathrm{Fe}-\mathrm{Co}-\mathrm{Ni}$ family, which possess highly similar physiochemical properties. This helps explain the conservation of $\mathrm{Ni}$ over evolutionary time as an essential micronutrient.

The high similarity in ligand-binding potential of transition metals means that in the event of a breakdown in endogenous metal homeostatic mechanisms, $\mathrm{Fe}^{2+}$ and $\mathrm{Ni}^{2+}$ (and probably $\mathrm{Co}^{2+}$, because it is a member of the Fe-Co-Ni family) are likely competitors in certain cellular processes with abnormally high cellular bioavailability/use of one adversely affecting either bioavailability or use of the other. This is supported by observations that elevating $\mathrm{Fe}^{2+}$ suppresses $\mathrm{Ni}^{2+}$ absorption and translocation in soybean (Glycine max; Cataldo et al., 1978), elevating $\mathrm{Ni}^{2+}$ reduces endogenous $\mathrm{Fe}$ concentration in a variety of dicots (Chen et al., 2009; Ghasemi et al., 2009; Kovacik et al., 2009; Nicholas and Thomas, 1954) and monocots (Brown et al., 1987; Hewett, 1953; Khalid and Tinsley, 1980; Koch, 1956; Misra and Dwivedi, 1977), and now in pecan, a deciduous polycarpic woody perennial tree crop. Findings by Temp (1991 (as cited by Seregin and Kozhevnikova, 2006) further support this possibility in that $\mathrm{Co}^{2+}$ was almost as inhibitory to $\mathrm{Ni}^{2+}$ absorption and translocation as $\mathrm{Fe}^{3+}$. It is therefore postulated that because of high physiochemical similarity [e.g., $r_{\text {rad }}$, charge density, and $e^{-}$configuration ( $\left.\mathrm{Ar}\right) 3 d^{7} 4 s^{2}$ for $\mathrm{Co}^{2+}$ vs. (Ar) $3 d^{8} 4 s^{2}$ for $\left.\mathrm{Ni}^{2+}\right] \mathrm{Co}^{2+}$ is also a strong $\mathrm{Ni}^{2+}$ antagonist in metabolic processes when present at relatively high concentration or when endogenous homeostatic processes break down during rapid organ growth.

Plant micronutrient homeostasis is highly regulated and likely coordinated within the whole plant through shoot-root communications (Grusak et al., 1999). The ability of pecan seedlings to maintain $\mathrm{Fe}-\mathrm{Ni}$ homeostasis was temporarily impaired when sudden high $\mathrm{Fe}$ availability led to high Fe concentration in young shoot and leaf tissues sufficient to suppress either physiological availability or use of endogenous Ni during early canopy growth. Although high endogenous $\mathrm{Fe}$ can increase the concentration of hydroxyl radicals (Halliwell and Gutteridge, 1992; Jeong and Connolly, 2009) and other oxidizers sufficient to disrupt physiological processes and subsequent growth, the correction of $\mathrm{Ni}$ deficiency symptoms in pecan by timely topical $\mathrm{Ni}$ application is suggestive that symptoms are primarily the result of insufficient bioavailable Ni rather than Fe toxicity (e.g., cytotoxic activity by Fe-associated hydroxyl radicals or other oxidizers). The observed concomitant increase in foliar concentration of several transition metals (i.e., $\mathrm{Ti}, \mathrm{V}, \mathrm{Cr}, \mathrm{Co}, \mathrm{Cu}, \mathrm{Zn}$, and $\mathrm{Mo}$ ) like with increasing Fe:Ni ratio, plus high metal concentration in $\mathrm{Ni}$-deficient foliage reported in previous studies (Wood et al., 2003a, $2003 \mathrm{~b}$ ), supports the possibility of a partial short-term breakdown in transition metal homeostasis. It may be that the plant adjusts to high $\mathrm{Fe}$ availability by increasing $\mathrm{Ni}$ uptake by roots, but in so doing, Ni uptake transporter(s) also take up physiochemically similar transition metals, which in turn further reduce $\mathrm{Ni}$ bioavailability/use within expanding shoots/foliage through competition with $\mathrm{Ni}$ and promiscuous binding to thiol, thioether, imidazole, and carboxylate ligands (as is characteristic of transition metals). Although speculative, disrupted homeostasis and subsequent putative downstream damage to cellular physiology might partially explain why non-timely foliar $\mathrm{Ni}$ application (i.e., applied after $\approx 10$ to $30 \mathrm{~d}$ of budbreak) to correct Ni deficiency-associated morphological symptoms is often ineffective (Wood et al., 2006a, 2006b).

It is apparent that DPTA alone can also trigger Ni deficiency; however, severity of deficiency is less with DPTA than with FeDPTA. It is important to note that the magnitude of a morphological based subjective scale (a non-linear scale) of severity of Ni symptoms is much greater between a rating of 7 to 8 than of 6 to 7 , so the DPTA treatment effect on induction of Ni deficiency symptoms was not nearly as profound as that of the Fe-DPTA treatment. This indicates that considerable loss of $\mathrm{Ni}$ bioavailability is the result of excessive Fe rather than DPTA chelation of Ni. This supports earlier reports that chelating agents are potentially absorbed into plant tissues (Tiffin and Brown, 1961; Tiffin et al., 1960; Weinstein et al., 1951). DPTA at sufficiently high concentration can be phytotoxic because of competitively sequestering essential elements from metalloenzymes or 

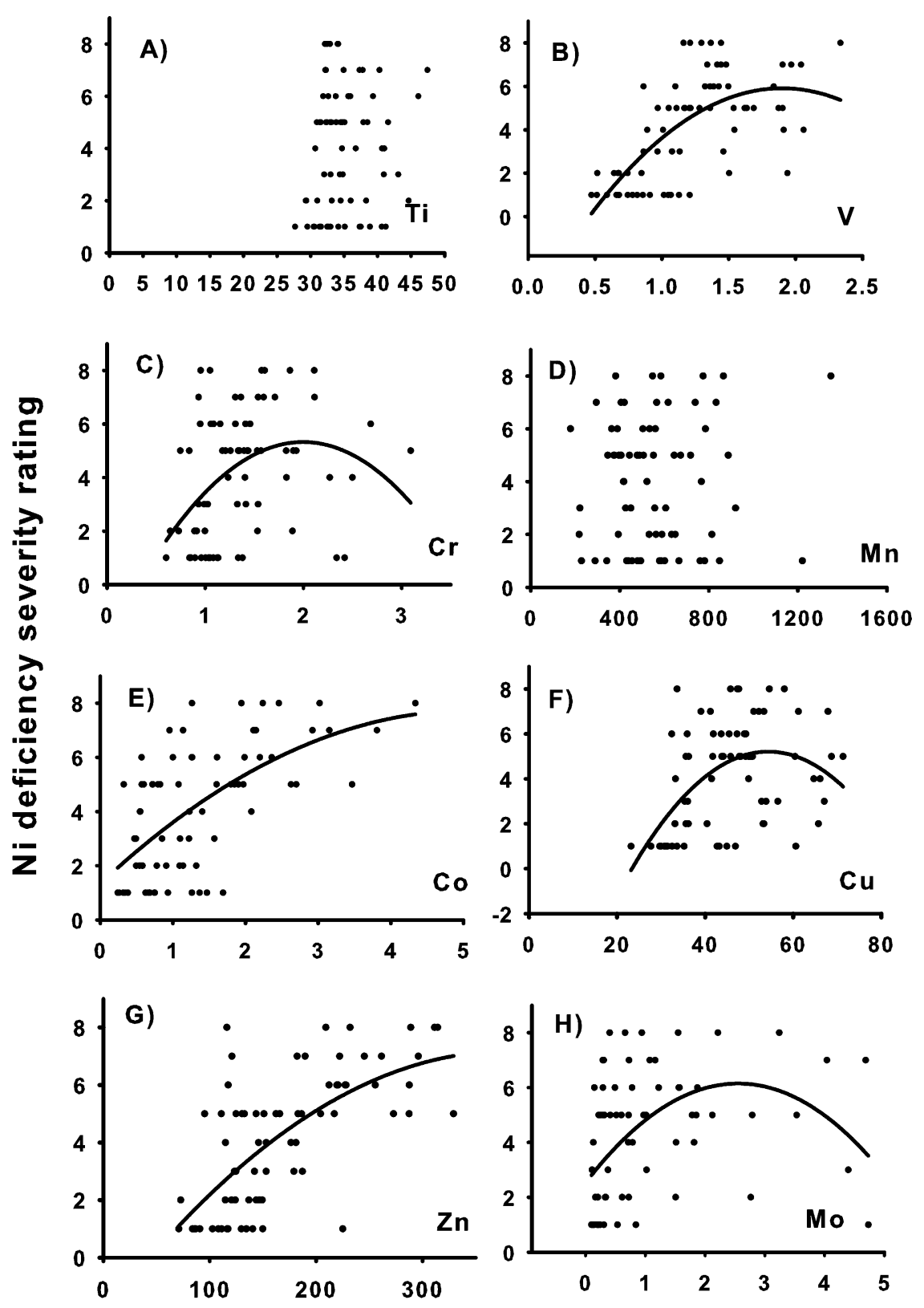

\section{Metal concentration (ug.g ${ }^{-1}$ )}

Fig. 5. Relationship between degree of nickel (Ni) deficiency $(y)$ of the apical-most shoot of pecan seedlings $\approx 14 \mathrm{~d}$ after budbreak and foliar concentration of various transition metals. Graphs without fitted functions (i.e., Ti and $\mathrm{Mn})$ were not statistically significant $(P \leq 0.05)$ quadratics. The relationship for $\mathrm{V}, \mathrm{Cr}, \mathrm{Co}, \mathrm{Cu}, \mathrm{Zn}$, and Mo were described by quadratic functions. For $\mathrm{V}, y=-4.324^{\mathrm{e}+0}$ $+1.078^{\mathrm{e}+1} x-2.839^{\mathrm{e}+0} x^{2} ; R^{2}=0.45, P<0.0001 ;$ for $\mathrm{Cr}, y=-2.220^{\mathrm{e}+0}+7.555^{\mathrm{e}+0} x-1.891^{e+0} x^{2} ; R^{2}=$ $0.17, P=0.0015$; for $\mathrm{Co}, y=1.340^{\mathrm{e}+0}+2.503^{\mathrm{e}+0} x-2.450^{\mathrm{e}-0} x^{2} ; R^{2}=0.39, P<0.0001$; for $\mathrm{Cu}, y=$ $-1.3083^{\mathrm{e}+1}+5.899^{\mathrm{e}-1} x-5.4230^{\mathrm{e} 30} x^{2} ; R^{2}=0.25, P<0.0001$; for Zn, $y=-2.00^{\mathrm{e}+0}+4.817^{\mathrm{e}-2} x-6.319^{\mathrm{e}+0}$ $x^{2} ; R^{2}=0.39, P<0.0003$; for Mo, $y=2.536^{\mathrm{e}+0}+2.831^{\mathrm{e}+0} x-5.546^{e-0} x^{2} ; R^{2}=0.22, P<0.0001$. Ti $=$ titanium; $\mathrm{Mn}=$ manganese $\mathrm{V}=$ valadium $; \mathrm{Cr}=$ chromium; $\mathrm{Co}=$ cobalt $; \mathrm{Cu}=$ copper $\mathrm{Zn}=$ zinc; $\mathrm{Mo}=$ molybdenum.

other physiologically active biomolecules (Albert, 1958). A relatively small amount of Fe-DPTA appears to be absorbed by roots and translocates to aerial organs where the cytoplasmic $\mathrm{pH}$ environment causes the chelate to release bound $\mathrm{Fe}$; hence, the resulting free chelate potentially sequesters other transition metal ions within cells, which in turn potentially reduces micronutrient bioavailability for a host of metabolic or physiological processes.
The ability of Fe-DPTA, and likely other Fe-chelates, to trigger Ni deficiency in young expanding foliage and shoots of pecan raises questions as to whether there are unintended consequences from spraying salts of chelates of other transition metal trace elements like $\mathrm{Zn}, \mathrm{Cu}$, or $\mathrm{Fe}$ on Ni-associated nutritional physiology of pecan orchards during early spring. Corrective sprays for Fe deficiency occur in orchards on relatively high $\mathrm{pH}$ soils with a history of Fe deficiency, as is often the case in certain southwestern U.S. pecan orchards. These soil environments are also conducive to low metal bioavailability within spring tissue for essential transition metals other than $\mathrm{Fe}$ (e.g., $\mathrm{Mn}, \mathrm{Cu}, \mathrm{Ni}, \mathrm{Zn}$ ). If tree organs are such that endogenous $\mathrm{Ni}$ is near the lower critical level, then the antagonistic effect of Fe-chelates on $\mathrm{Ni}$ might trigger $\mathrm{Ni}$ deficiency. This deficiency might be either a "hidden hunger" effect on tree physiology or a more pronounced "visual symptom" effect on pigmentation or morphology.

The antagonistic action of $\mathrm{Fe}$ on $\mathrm{Ni}$ observed here, and the $\mathrm{Ni}$ on $\mathrm{Fe}$ antagonism noted in other crops, is consistent with evidence indicating a long evolutionary metabolic interrelationship between $\mathrm{Ni}$ and $\mathrm{Fe}$ with the environmental $\mathrm{Fe}$ :Ni ratio affecting relative dependence of evolving organisms on the two elements. Life forms evolving during the Great Oxidation Event $(\approx 2.4$ billion years ago; i.e., an environment becoming dominated by $\mathrm{O}_{2}, \mathrm{~N}_{2}$, and $\mathrm{CO}_{2}$ ) coped with changing metal availability to reduce the breadth of $\mathrm{Ni}$ dependency for redox transformations in enzymes and structural integrity of peptides and proteins (Konhauser et al., 2009). With the relatively high Fe:Ni ratio present today in surface soils, Ni now plays a relatively minor, yet still essential, role in higher organisms. Most former key $\mathrm{Ni}$-associated catalytic roles are now replaced by $\mathrm{Fe}$ or other transition metals [i.e., $\mathrm{Zn}$ for enzymes requiring an electrophile; and Mo, $\mathrm{Cu}$, and $\mathrm{Mn}$ as brokers of redox transformations (de Silva and Williams, 2006; Merchant, 2010)] as they became increasingly available to plants, relative to $\mathrm{Ni}$, in a long-lived oxidizing atmosphere. Today, any enzymes using Ni are likely to be metal relics from the Archaean Eon (Konhauser et al., 2009; Waldon et al., 2009). Although there was a reversal of the relative dominance of $\mathrm{Ni}$ and $\mathrm{Fe}$ for associated redox metabolism over evolutionary time, the metabolic essentiality of $\mathrm{Ni}$ in higher plants is nevertheless conserved as an essential cofactor for optimal urease activity and associated ammonia generation (Dixon et al., 1975, 1980a, 1980b). There also appears to be other conserved roles for $\mathrm{Ni}$ in a few other enzymes of higher plants (Das et al., 1978; Pandolfini et al., 1992; Schickler and Caspi, 1999; Webster et al., 2004), especially in ureide-N-transporting species like pecan (Bai et al., 2006, 2007), but such roles remain to be proven.

\section{Conclusions}

The present study demonstrates that 1) cellular Ni bioavailability/use is potentially diminished by excessive elevation of endogenous concentration of either Fe or its DPTA chelant; 2) various morphological forms of severe Ni deficiency are inducible by elevating endogenous $\mathrm{Fe}$ and/or DPTA; 3) relatively high tissue $\mathrm{Fe}$ and/or DPTA disrupts $\mathrm{Ni}$ homeostasis; and 4) Fe-DPTA or DPTAinduced Ni deficiency is preventable or correctable by timely topical application of $\mathrm{Ni}$ to 
Table 3. Efficacy of specific transition metals for correcting iron-diethylenetriaminepentaacetic acid (FeDPTA) induced nickel (Ni) deficiency symptoms when applied as a foliar spray to young shoots of 'Desirable' pecan seedlings within $7 \mathrm{~d}$ of budbreak.

\begin{tabular}{lcccccccccc}
\hline & \multicolumn{7}{c}{ Severity of Ni deficiency after treatment with one of several transition metals } \\
\cline { 2 - 9 } Shoot treatment & Titanium & Valadium & Chromium & Manganese & Iron & Cobalt & Ni & Copper & Zinc & Molybdenum \\
\hline Symptomatic control & 8 & 8 & 8 & 8 & 8 & 8 & 8 & 8 & 8 & 8 \\
Transition metal & 8 & 8 & 8 & 8 & 8 & 8 & 1 & 8 & 8 & 8 \\
Significance & $\mathrm{NS}^{\mathrm{x}}$ & $\mathrm{NS}$ & $\mathrm{NS}$ & $\mathrm{NS}$ & $\mathrm{NS}$ & $\mathrm{NS}$ & $* * *$ & NS & NS & NS \\
\hline
\end{tabular}

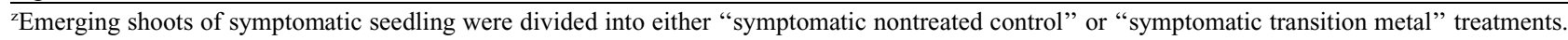

'Transition metals were applied as foliar sprays of sulfate, chloride, or nitrate salts.

${ }^{\mathrm{x}}$ Severity of $\mathrm{Ni}$ deficiency was assessed in mid May, $\approx 4$ weeks after treatment, according to the following rating scale identifying a progression in degree of visible Ni deficiency symptoms: $1=$ no Ni-associated morphological distortions of any compound leaves or leaflets on shoots (i.e., normal appearance); $2=25 \%$ or less of leaflets on most severely distorted compound leaf exhibiting morphological distortions (i.e., slightly blunted leaflet apex); $3=26 \%$ to $50 \%$ of leaflets on this compound leaf exhibiting some degree of morphological distortion; 4 = greater than $50 \%$ of leaflets on this compound leaf exhibiting morphological distortion; $5=\# 4$, plus leaflet cupping; $6=\# 5$, plus necrosis of leaflet tips; $7=\# 6$, plus necrosis of leaflet margins, plus crinkled and dwarfed leaflets; $8=\# 7$, plus dwarfed shoots (i.e., short internodes); $9=\# 8$, plus rosetting; and 10 =\#9, plus shoot death (Nyczepir et al., 2006; Wood, 2010; Wood et al., 2003a; 2003b). Significance by analysis of variance is such that $* * *=P \leq 0.0001 ;$ Ns $=$ not significant at $P \leq 0.05$.

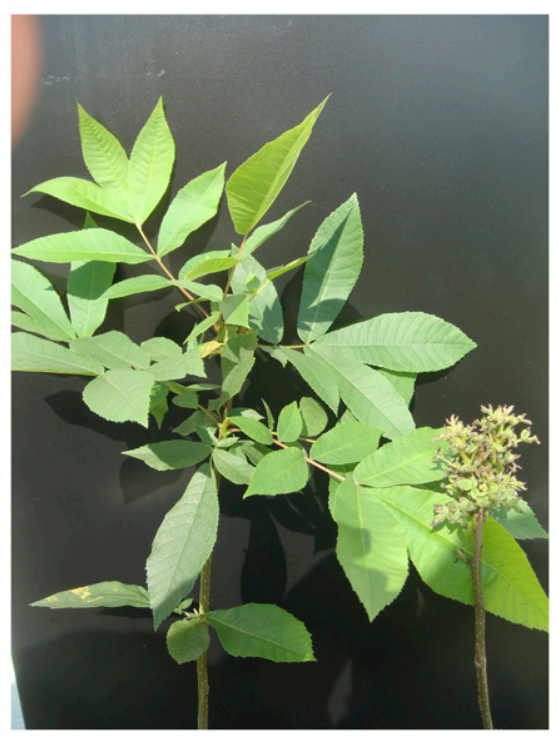

Fig. 6. The Fe-DPTA-treated seedling tree on the left received a foliar spray of nickel (Ni)-sulfate when first exhibiting Ni deficiency symptoms at budbreak, whereas the Fe-DPTA-treated seedling on the right did not receive a followup Ni spray. Timely Ni treatment rapidly and effectively corrects expression of Fe-DPTAinduced Ni deficiency symptoms. Fe-DPTA = iron-diethylenetriaminepentaacetic acid.

affected organs. These studies support the likelihood that $\mathrm{Fe}$ and $\mathrm{Ni}$ are mutually antagonistic with tissue toxicity by one being reversible by increasing tissue concentration of the other or that deficiency of one is enhanceable by increasing tissue concentrations of the other. Exposure of trees, possessing an endogenous $\mathrm{Ni}$ concentration below, or near, the lower critical concentration, to excessive Fe or DPTA can trigger either Ni hidden hunger or visible morphological deficiency. Because $\mathrm{Cu}$ and $\mathrm{Zn}$, and now $\mathrm{Fe}$ and DPTA, can antagonize Ni nutritional physiology, excessive fertilization, or excessive soil or cellular availability, of any one or combination of these three metals or chelating agents possess potential for triggering $\mathrm{Ni}$ deficiency, especially if $\mathrm{Ni}$ bioavailability/ use is already marginal. This raises the possibility of heretofore-unrecognized transition metal-induced $\mathrm{Ni}$ deficiency occurring in a wide variety of crop species, especially

Table 4. Influence of iron-diethylenetriaminepentaacetic acid (Fe-DTPA)or diethylenetriaminepentaacetic acid (DTPA)applied as either a soil drench or foliar spray to pecan seedlings at budbreak and the ability of timely nickel $(\mathrm{Ni})$ sprays to prevent deficiency.

\begin{tabular}{lcc}
\hline & \multicolumn{2}{c}{ Ni deficiency severity rating at 4 weeks post-budbreak } \\
\cline { 2 - 3 } Treatment $^{\mathrm{z}}$ & $\begin{array}{c}\text { Expt. 1: Fe-DPTA and DPTA } \\
\text { applied as a soil drench }\end{array}$ & $\begin{array}{c}\text { Expt. 2: Fe-DPTA and DPTA } \\
\text { applied as a foliar spray }\end{array}$ \\
\hline Control & $2.6 \mathrm{c}^{\mathrm{x}}$ & $3.4 \mathrm{c}$ \\
DPTA & $6.8 \mathrm{~b}$ & $6.0 \mathrm{~b}$ \\
Fe-DPTA & $8.3 \mathrm{a}$ & $7.7 \mathrm{a}$ \\
Control + Ni & $1.0 \mathrm{~d}$ & $1.0 \mathrm{~d}$ \\
DPTA + Ni & $1.0 \mathrm{~d}$ & $1.1 \mathrm{~d}$ \\
Fe-DPTA + Ni & $1.2 \mathrm{~d}$ & $1.1 \mathrm{~d}$ \\
\hline
\end{tabular}

${ }^{2}$ DPTA and Fe-DPTA applied to soil at $500 \mathrm{mmoles} /$ pot or to foliage at $3 \mathrm{~mm}$. Ni was applied as a foliar spray $(\mathrm{Ni}$ at $2 \mathrm{~mm}) \approx 7 \mathrm{~d}$ after budbreak in Expt. 1 and at $7 \mathrm{~d}$ and $10 \mathrm{~d}$ after budbreak in Expt. 2 .

${ }^{y}$ Severity of Ni deficiency was assessed in mid-May, $\approx 4$ weeks after treatment, according to the following rating scale identifying a progression in degree of visible Ni deficiency symptoms: $1=$ no Ni-associated morphological distortions of any compound leaves or leaflets on shoots (i.e., normal appearance); $2=25 \%$ or less of leaflets on most severely distorted compound leaf exhibiting morphological distortions (i.e., slightly blunted leaflet apex); $3=26 \%$ to $50 \%$ of leaflets on this compound leaf exhibiting some degree of morphological distortion; $4=$ greater than $50 \%$ of leaflets on this compound leaf exhibiting morphological distortion; $5=\# 4$, plus leaflet cupping; $6=\# 5$, plus necrosis of leaflet tips; $7=\# 6$, plus necrosis of leaflet margins, plus crinkled and dwarfed leaflets; $8=\# 7$, plus dwarfed shoots (i.e., short internodes); $9=\# 8$, plus rosetting; and $10=\# 9$, plus shoot death (Nyczepir et al., 2006; Wood, 2010; Wood et al., 2003a; 2003b). ${ }^{x}$ Treatment means followed by different letters (i.e., a non-common letter) are significantly different by Tukey's honestly significant difference at $P \leq 0.05$ level.

with use of Fe-DPTA or other Fe-chelates in nutrient management programs. If so, then the likelihood is probably greatest in ureide-N transporting crop species, like pecan, in which $\mathrm{Ni}$ appears to be required at higher concentrations than by amide-N-dominant species. These findings indicate that there is reason to consider the widespread existence of non-diagnosed $\mathrm{Ni}$ deficiency problems in crops grown on soil situations enabling high availability of $\mathrm{Fe}$ and perhaps other transition metals possessing physiochemical properties similar to $\mathrm{Ni}^{2+}$. These results indicate that soil substrates high in bioavailable or chelated $\mathrm{Fe}$ can trigger $\mathrm{Ni}$ deficiency. This antagonistic effect of Fe and DPTA on Ni nutritional physiology is important to the production of certain horticultural and agronomic crops and therefore merits consideration in development of mineral nutrient management strategies.

\section{Literature Cited}

Albert, A. 1958. Metal-binding agents in chemotherapy: The activation of metals by chelation, p. 112-138. In: Cowan and Rowatt (eds.). The strategy of chemotherapy. Soc. For Gen. Microbiol. 8th Symp. Cambridge Univ. Press, Cambridge, UK.
Bai, C., C.C. Reilly, and B.W. Wood. 2006. Nickel deficiency disrupts metabolism of ureides, amino acids, and organic acids of pecan foliage. Plant Physiol. 140:433-443.

Bai, C., C.C. Reilly, and B.W. Wood. 2007. Nickel deficiency affects nitrogenous forms and urease activity in spring xylem sap of pecan. J. Amer Soc. Hort. Sci. 132:302-309.

Brown, P.H., R.M. Welch, and E.E. Cary. 1987. Nickel: A micronutrient essential for higher plants. Plant Physiol. 85:801-803.

Brown, P.H., R.M. Welch, and J.T. Madison. 1990. Effect of nickel deficiency on soluble anion, amino acid, and nitrogen levels in barley. Plant Soil 125:19-27.

Carter, E.L., D.E. Tronrud, S.R. Taber, P.A. Karplus, and R.P. Hausinger. 2011. Ironcontaining urease in a pathogenic bacterium. Proc. Natl. Acad. Sci. U. S. A. 102:13095-13099.

Cataldo, D.A., T.R. Garland, and R.E. Wildung. 1978. Nickel in plants. Plant Physiol. 62, I, 563; II, 566 .

Chaney, R.L., J.C. Brown, and I.O. Tiffin. 1972. Obligatory reduction of ferric chelates in iron uptake by soybeans. Plant Physiol. 50:208-213.

Chen, Z., T.T. Watanabe, T. Shinano, J. Exawa, K. Washaki, T. Kimura, M. Osaki, and Y. Xhu. 2009. Element interconnections in Lotus japonicas: A systematic study of the effects of element additions on different natural variants. Soil Sci. Plant Nutr. 55:91-101. 
Das, P.K., M. Kar, and D. Mishra. 1978. Nickel nutrition of plants: Effect of nickel on some oxidase activities during rice (Orzya sative L.) seed germination. Zeitschrift Pflanzenphysiologie 90:225-233.

de Silva, J.J.R.R. and R.J.P. Williams. 2006. The biological chemistry of the elements: The inorganic chemistry of life. $2^{\text {nd }}$ Ed. Oxford University Press Inc., New York, NY.

Dixon, N.E., C. Gazzola, R.L. Blakeley, and B. Zerner. 1975. Jack bean urease (EC 3.5.1.5) a metalloenzyme: A simple role for nickel. J. Amer. Chem. Soc. 97:4131-4133.

Dixon, N.E., P.W. Riddles, C. Gazzola, R.L. Blakeley, and B. Zerner. 1980a. Jack bean urease (EC 3.5.1.5) II: The relationship between nickel, enzymatic activity, and the 'abnormal' ultraviolet spectrum and the nickel content of jack beans. Can. J. Biochem. 58: 474-480.

Dixon, N.E., R.W. Riddles, C. Gazzola, R.L. Blakeley, and B. Zerner. 1980b. Jack bean urease (EC 3.5.1.5) V: On the mechanism of action of urease on urea, formamide, acetamide, N-methylurea, and related compounds. Can. J. Biochem. 58:1335-1344.

Ghasemi, R., S.M. Ghaderian, and U. Kramer. 2009. Interference of nickel with copper and iron homeostasis contributes to metal toxicity symptoms in the nickel hyperaccumulator plant Alyssum inflatum. New Phytol. 184:566-580.

Grusak, M.A., J.N. Pearson, and E. Marentes. 1999. The physiology of micronutrient homeostasis in field crops. Field Crops Res. 60:41-56.

Halliwell, B. and J.M.C. Gutteridge. 1992. Biologically relevant metal ion-dependent hydrosyl radical generation. FEBS Lett. 307:108-112.

Hewett, E.J. 1953. Metal interrelationship in plants. J. Expt. Bot. 4:59-64.

Jeong, J. and E.L. Connolly. 2009. Iron uptake mechanisms in plants: Functions of the FRO family of ferric reductases. Plant Sci. 176:709714.

Kabata-Pendias, A. 2001. Trace elements in soils and plants. CRC Press, Boca Raton, FL.

Khalid, B.Y. and J. Tinsley. 1980. Some effects of nickel toxicity on rye grass. Plant Soil 55:139144.

de Koch, P.C. 1956. Heavy metal toxicity and iron chlorosis. Ann. Bot. (Lond.) 20:133-141.

Konhauser, K.O., E. Pecoits, S.V. Lalonde, D. Papineau, E.G. Nisbet, M.I. Barley, N.T. Arndt, K. Zahnle, and B.S. Kamber. 2009. Oceanic nickel depletion and a methanogen famine before the Great Oxidation Event. Nature 458: $750-754$.

Kovacik, J., B. Klejdus, and J. Hedbavny. 2009. Nickel uptake and its effect on some nutrient levels, amino acid contents and oxidative status in Matricaria chamomilla plants. Water Air Soil Pollut. 202:199-209.

Kramer, U. and S. Clemens. 2006. Functions and homeostasis of zinc, copper, and nickel in plants. Topics in Current Genet. 14:216-271.

Merchant, S.S. 2010. The elements of plant micronutrients. Plant Physiol. 154:512-515.

McGlashan, M.L. 2010.27 Aug. 2013.<http://www. kayelaby.npl.co.uk/chemistry/3_7/3_7_6.html>.

Misra, S.G. and R.S. Dwivedi. 1977. Residual effect of iron-nickel interactions on the availability of nutrients. Plant Soil 48:705-708.

Nicholas, D.J.D. and W.D.E. Thomas. 1954. Some effects of heavy metals on plants grown in the soil culture, part III. The effect of nickel on fertilizer and soil phosphate uptake and Fe and Ni status of tomato. Plant Soil 5:182-193.

Nieboer, E. and D.E.S. Richardson. 1980. The replacement of the nondescript term 'heavy metals' by a biologically and chemically significant classification of metal ions. Environ. Pollution Ser. B 1:3-6.

Nielsen, F.H., E.O. Uthus, and C.D. Hunt. 1982. Interactions between the 'newer' trace elements and other essential nutrients, p. 165 173. In: Dunckley, J.V. (ed.). New Zealand Workshop on Trace Elements in New Zealand Proc. University of Otago, Dunedin, New Zealand.

Nishida, S., A. Aisu, and T. Mizuno. 2012. Induction of IRT1 by the nickel-induced irondependent response in Arabidopsis. Plant Signal. Behav. 7:13-19.

Nyczepir, A.P., B.W. Wood, and C.C. Reilly. 2006. Association of Meloidogyne partityla with nickel deficiency and mouse-ear of pecan. HortScience 41:402-404.

Pandolfini, T., R. Gabbrielli, and C. Comparini. 1992. Nickel toxicity and peroxidase activity in seedlings of Triticum aestivum L. Plant Cell Environ. 15:719-725.

Romheld, V. and H. Marschner. 1986. Evidence for a specific uptake system for iron phytosiderophores in roots of grasses. Plant Physiol. 80: 175-180.

Schickler, H. and H. Caspi. 1999. Response of antioxidative enzymes to nickel and cadmium stress in hyperaccumulator plants of genus, Alyssum. Physiol. Plantarium. 105:39-44.

Sekhon, B.S. 2010. Metallochaperones-An overview. Current Chem. Biol. 4:173-186.

Temp, G.A. 1991. Nickel in plants and its toxicity: Resistance of wild species to heavy metals, p. 139-146. In: Alekseeva-Popova, N.V. (ed.). Lenuprizdat, Leningrad, Russia.

Tiffin, L.O. and J.C. Brown. 1961. Selective absorption of iron from iron chelates by soybean plants. Plant Physiol. 36:710-714.
Tiffin, L.O., J.C. Brown, and R.W. Krauss. 1960 Differential absorption of metal chelate components by plant roots. Plant Physiol. 35:362367.

Waldon, J.J., J.C. Rutherford, D. Ford, and N.J. Robinson. 2009. Metalloproteins and metal sensing. Nature 460:823-829.

Wallace, A., E.M. Romney, and J.W. Cha. 1977a. Nickel-iron interaction in bush beans. Commun. Soil Sci. Plant Anal. 8:787-790.

Wallace, A., E.M. Romney, J.W. Cha, S.M. Soufi, and F.M. Chaudhry. 1977b. Nickel phytotoxicity in relationship to soil $\mathrm{pH}$ manipulation and chelating agents. Commun. Soil Sci. Plant Anal. 8:757-764.

Webster, C.E., M.Y. Darensbourg, P.A. Lindahl, and M.B. Hall. 2004. Structures and energetics of models for the active site of acetylcoenzyme A synthase: Role of distal and proximal metals in catalysis. J. Amer. Chem. Soc. 126:3410-3411.

Welch, R.M. and R.D. Graham. 2005. Agriculture: The real nexus for enhancing bioavailable micronutrients in food crops. J. Trace Elem. Med. Biol. 18:299-307.

Weinstein, L.H., W.R. Robbins, and H.F. Perkins. 1951. Chelatin agents and plant nutrition. Science 120:41-43.

Wood, B.W. 2010. Nickel deficiency symptoms are influenced by foliar $\mathrm{Zn}: \mathrm{Ni}$ and $\mathrm{Cu}: \mathrm{Ni}$ concentration ratio. Acta Hort. 868:163-169.

Wood, B.W., R. Chaney, and M. Crawford. 2006a. Correcting micronutrient deficiency using metal hyper accumulators: Alyssum biomass as a natural product for nickel deficiency correction. HortScience 41:1231-1234.

Wood, B.W., C.C. Reilly, and A.P. Nyczepir. 2006b. Field deficiency of nickel in trees: Symptoms and causes. Acta Hort. 721:83-97.

Wood, B.W., C.C. Reilly, and A.P. Nyczepir. 2003a. Mouse-ear of pecan: I. Symptomology and occurrence. HortScience 38:87-94.

Wood, B.W., C.C. Reilly, and A.P. Nyczepir. 2003b. Mouse-ear of pecan: II. Influence of nutrient applications. HortScience 38:95100

Wood, B.W., C.C. Reilly, and A.P. Nyczepir. 2004. Mouse-ear of pecan: A nickel deficiency. HortScience 39:1238-1242.

Woolhouse, H.W. 1983. Toxicity and tolerance in the responses of plants to metals, p. 245-300. In: Lange, O.L., P.S. Nobel, C.B. Osmond, and H. Ziegler (eds.). Encyclopedia of plant physiology. Vol. 12C. Springer, Berlin, Germany.

Yamada, T., R.J. Kremer, P.R. de Camargo-Castro, and B.W. Wood. 2009. Glyphosate interactions with physiology, nutrition, and diseases of plants: Threat to agricultural sustainability? Eur. J. Agron. 31:111-113. 